\title{
The Homogeneity of Igbo Culture
}

\author{
Happiness C. Ogbu \\ Department of Industrial Design \\ Modibbo Adama University of Technology, Yola \\ ogbuchinyere2@gmail.com 08036059159
}

\section{Doi:10.5901/mjss.2013.v4n6p393}

\section{Abstract}

The focus of this work is on the Igbo east of the Niger. Their territory lies within latitude 5-70 North and longitude 6-80east, covering an area of 4106.2 square kilometers, with a population density of 800 people per square kilometer. Excavations in Igbo territories reveal the existence of ancient lgbo settlement. The lgbo language has been spoken for four thousand years, a fact which attests the antiquity of Igbo culture. The cultural complex of the lgbo people are found all over lgbo land in one form or another. This study reconstructs the cultural history of the lgbo people. The objective was to infield and showcase the lgbos as homogenous in their culture. The methodology relied on recorded and documented materials and literature. It also used data derived from archaeological and the distribution of material culture, diagrams/maps and other non-material culture complexes that occur in the lgbo land.

\section{Introduction}

The Igbo occupy the geographical space of southern Nigeria. There are neighboring cultural groups that define the boundaries of the Igbo territory. They are people of the Ika, Niger-Delta to the west of the Niger River. There is of course a population spill of the Igbo people to the west of the Niger River often described as the west Niger Igbo. To the North and Northwest are the Igala and Idoma and the southeast the Efik-Ibibio (Obayemi 1980).

The Igbo territory proper, the focus of our study lies to the east of the Niger River and is clearly definable in space between "Latitude 5- 7 north and longitude 6- 8 degrees east and covers approximately 41604.2 square kilometer" (Uchendu 1965).Studies by Morgan (1959), Karmon (1966) and Afigbo (1981) do suggest that the Igbo territory lay originally in a heavily forested environment.

But as a result of intensive cultivation of the soil especially in the North, the original rainforest has disappeared except along the valleys. This was replaced by secondary grass cover which karmon (1966) refers to as "the derived savannah". The southern portion of Igbo land came to be dominated by palm belt environment. Afigbo (1981) is of the view that the Igbo primary core with its nucleus along the Enugu covers such area as Awka, Okigwe, Owerri and Orlu. These Areas are marked by the incidence of high population density often rising to 800 people per square kilometer in orlu, Enugu-Ezikwe e.t.c. Morgan (1959) describes these village settlement here as Grass land town given their high population density.

\section{Igbo pre- history}

Igbo prehistory is contained in archaeological evidences and documentations. Excavations carried out by Shaw (1970) in Igbo -ukwu indicate a data of 805A.D for bronze and other artifacts. At this time, it was believe that Igbo social, political and religious institutions were rightly positioned and stable enough (Onwuejeogwu 1981). The data of 805 A.D. for Nwankwo site in Bende and another data of the University of Nigeria form (Hartle 1967) point to the antiquity of human settlements in the Igbo area. In addition, theexcavation of a rock shelter at Afikpo (chikwendu and umeji 1983) further support the existence of ancient settlement in the Igboterritory. Evidence from glottochronology (Afigbo 1981), suggests that the Igbolanguage belongs to Niger- Congo languagecomplex with it sub-unit of kwa language of which Igbo language forms a part. Not much can be said of Igbo prehistory, except for evidences coming from few archaeological excavations carried out in the Igbo territory.

The Igbo unlike other peoples such as the ljaw were isolated from European contact at a time when the ljaw people were trading with the Portuguese in human cargoes. Later, this was replaced by palm oil trade (Dike 1956, Jones 
1970).The Igbo formed the bulk of the slaves sold to the Europeans, although one of them by name Jaja rose to buy off his freedom. He founded the important town of Opobo. It was in the $19^{\text {th }}$ century with the advent of colonial activities in African that the Igbo come into colonial records in their contact with the British.

Afigbo (1981) says that the Igbo had no record traditions of origin. When people were asked about their origin, they would simply point to the earth. This Afigbo (1981) sees as indication of the antiquity of Igbo culture since people would seem to have lost all stories about their origin. However, the Igbo are said to have migrated from the north of Niger-Benue confluence and settled along the fringe of the rainforest of southeast Nigeria (Abayomi, 1980). From here they settled at Okigwe-Enugu ceusta. This location was considered less wet than the lower plains and easier to cultivate. With the increasing exhaustion of land, some of the southern Igbo group in the area of Isuama moved towards the west of the cross river to establish the territories now occupied by the Ohafia and Arochukwu people e.t.c.

Others spread out fan -like to the north east in the present area occupied by the Izzi and Ezikwo to the Nsukka region up to Opi before pushing up northward to form an arrowhead. This is the territory now occupied by the dense population of the various peoples of Enugu Ezike with their neighboring people of Idomaand Igala to the North and West of them (Afigbo 1981). This pattern of dispersal of people in the Igbo territory did not deter the Igbo from holding on to their homogenous culture. This is as a result of their very strong ties with their cosmology which were deeply rooted in the general acceptance of their tradition such as the cutting of kola nut, pouring of liberation, undisputable use and adoption of "Ofo" staff of truth and justices and the distinctive features of their title taking. Other areas of strong bounds include their religious concepts of "Chukwu Okike" God the creator and other smaller gods and spirits such as "alusi", "mmuo", "ahajioku" and the ideology of abomination "nso ala" which cut across the entire Igbo land and made manifest in their artistic, social, religious as well as political traditions and pattern of leadership (Onwuejeowu 1981).

Culturally the Igbo live in patrilineages called "Ummunna".Patrilineages are ranked from minimal to maximal. Patrilineages of variable depth and span of diverse origins fedeated to become villages. Groups of villages federated to form town called "Obodo". Towns are generally dispersed, especially among the Igbo east of the Niger, but are more compact among the Igbo west of the Niger. Mixed, dispersed and compact settlements are also found in Igbo nation. Furthermore, evidences based on genealogical materials and cross checked againstoral traditions and the evidences on archaeological and linguistic data proved that major movements /improvements account for their settlement, where ever they are found in the Igbo culture areas (onwuejeogwu 1981)

Fig. 1 and 2

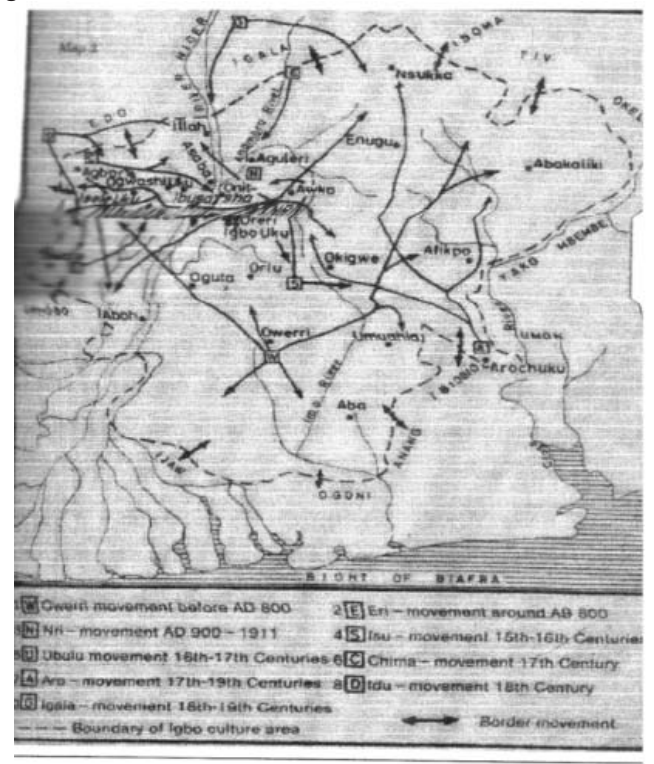

Fig. 1 The Igbo Culture Area

Sonurce: Onwwejeogen 1981

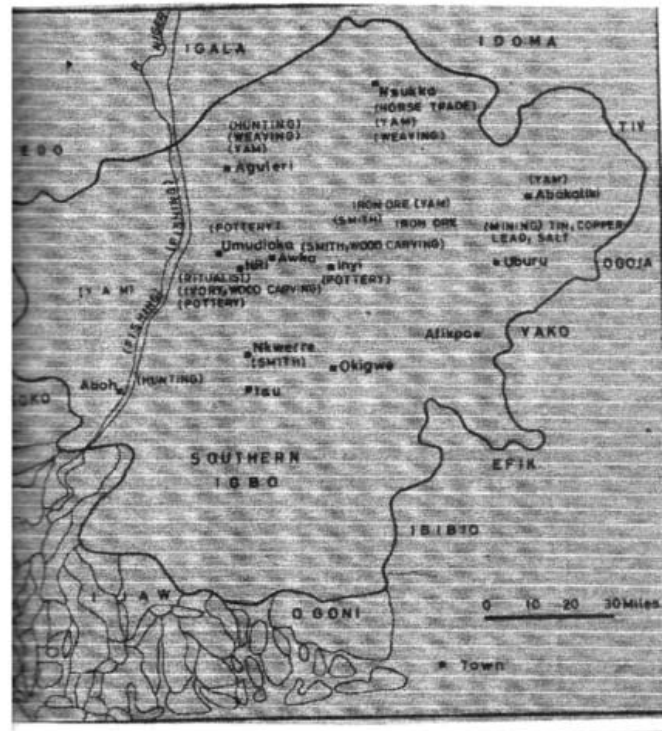

Fig. 2 Oecupational Specialization in Northern Igbo Culture Area.

Source: Onwuejeogwu 1981. 


\section{The Igbo people}

Stretching across the river Niger from West of Agbor to the fringes of cross River and running roughly from North of Nsukka highlands to some parts of the Atlantic coast live a dynamic people whose indigenous language is Igbo. According to F.C. Ogbalu, they are of average height, mostly dark in complexion, thickly built with road nose, curlyblack hair and moderately thick lips (Ogbalu).

Plate: 1

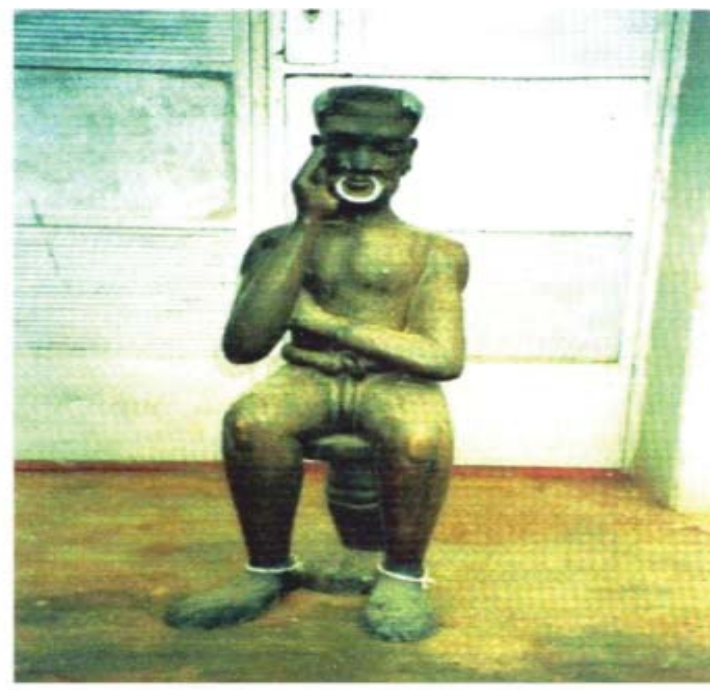
Plate 1 A wood sculpture of an early titled ozo
man seated on a title stool

He further commented that "the meaning and origin of this word Igbo, is still unknown. It is also not certain from when, where and how the Igbo came to occupy their presence place of Abode" authors, such as Afigbo (1981), Basden (1966), Anakor (1984), Uchendu 1965, and Ogbalu link them with the Hebrew; the biblical lost of Israel who after contact with ancient Egypt were pushed south wards as a result of Arab invasion of North African. Nevertheless, majority of Igbos believe that they were indigenous to the area they now occupy. They believe "Chineke" God created and planted them where they are now, a fact which attest to their notion of "nfu n' ala" which translates as sprouting from the soil and points to the antiquity of their existence. Again with regards to the growth of the characteristic lgbo cosmology in Afigbo (1981), the Nri corpus of myth makes mention of "Chukwu" God who after creating man, sent smith to dry the land, making the land bring forth food and instituting the market days.

Eliade (1987) stated that the Igbo are the largest ethnic group of southern Nigeria. Afigbo (1981) supported that their population is estimated between 12 and 14 million today. Until recently, the overwhelming majority of Igbo were farmers, raising yam as their staple crop. "Traditionally, they lived in villages or village- groups surrounding by their farms. The village-group was the primary unit of political authority; there was no sustained tradition of centralized states within Igbo society. Rather there were strong ties to the village community, the extended family system, age-group association and various religious organizations that were important in community life". The Igbo have exposed to Christian missionary activities since 1957, when a mission was opened at the important town of Onitsha along the Niger River. By the midtwentieth century most Igbo have adopted Christianity, though Igbo traditional religion still has millions of devotes (Eliade 1987).

\section{The Igbo cosmology}

Eliade distinguished types of supernatural beings in Igbo religions, "God the creator, the spirit and the ancestors." He further added that the Igbo believe that God "Chukwu okike" is the only supreme being: that he created heaven and earth 
"Enu na ala" that he lives above and made earth his footstool. They also believe that he cannot be comprehended "Amachaghi amacha". The Igbo honour him by naming their children in praise of him with such name as "ike Chukwu" God's power, "Chukwunyere" God giveth, "Chukwuebuka" God is great e.t.c. He is acknowledged as all powerful and all provider. Thay also believe that he does not intervene in small matters of human existence for such he lives to the spirits and the ancestors who are seen as his messengers.

Spirit "arusi" are powerful beings. Some of them are personified and believe to inhibit physical phenomena such as the trees "oke osisi," valleys "ndagwurugwu" rivers "osimiri" mountains "ugwu" and thunders storm "egbe eluigwe"e.t.c. There is also a spirit which is associated with the four days of Igbo market days namely: Eke, Orie, Afor and Nkwo. These words have no English equivalence. The Igbo also believe that an individual personal destiny is associated with a type of spirit called "chi", who directs the affairs of the individual. There is also a spirit known as "ani" the earth goddess who is worshipped throughout the Igbo land. This spirit is regarded as a person and treated as such. It has a shrine known as "Ihu ala", priest and festival which is celebrated. There is another spirit called "Ahajioku," yam spirit which is also celebrated yearly. There exist benevolent spirits which bring good fortunes and malevolent ones which are associated with wickedness, bad fortunes and troubles. These spirits receive no daily attentions but when they strike or manifest they are placated and atoned to leave human beings alone.

The Igbo believe in reincarnation, and reward after death, those who died well will join the ancestor's realm. After death, a person reincarnates seven times before he finally dies and disappears into the spirit world, hence the Igbo saying "uwam uwa asaa" which translates as my world of seven circles. The ancestors retain a close relationship with their descendants. They are involved during prayers using kola nuts "Oji," palm wine "Mamanya" and sacrifices such as fowls "Okuko" and goat "Ewu". Other material items are also offered to them. The Igbo celebrate each major stages of an individual with rituals. These stages include "Omumu" birth, "igu aha" naming ceremony, "Ito okoro" puberty, "Olulu" marriage, "ichi echi- chi" title taking and "Ikwa ozu" funeral rites. These are to ensure successful passages into the next level of existence.

Sacrifice he noted are important in Igbo religion. They are offered for the expiration of sins and for the following reasons: protection "mkpuchte," assistance "enyemaka" and for thanksgiving "onyinye ekene". Sacrifice at family level are performed by "Di okpara" the senior male in the family and at the village level by the village head "okenye obodo" or the chief priest "Onye isi mmuo" (Eliade 1978). On the other hand, Ogbalu supported this passion when he wrote that "family is a very important institution among the Igbo. It is called "Ezi na Ulo" which translates as "outside relations and those within the house" and differs from the English concept of family which apply only to a men, his wife and children. The Igbo concept of family permeates other relations such as the in-laws "Ndi Ogo".

The people believe that they own a great deal of responsibility to all with whomthey are related. This concept of family has been the source of strength and weakness to them. A person who is "lifted up" in a family owes a moral duty to life up others below him as much as possible. From the family, responsibility spreads to the "Umunna" kinsmen, to the village clans men and finally to the town "Obodo" in a lesser degree. It also extends to one's relations in other towns suchas "ndi ogo" in-laws, "Umere nne" one's mothers relations and "Nna ochie".

Moral codes noted Nwala (1985) are firmly rooted in Igbo religion. This is stressed by the Igbo use of words "Omenala" which translate as "that which happens in the land". Theft is particularly regarded as a grievous sin. The most serious crime is abominations committed against the earth "ala". These include "Ikwu Udo" suicide, "Ikwa Iko n'ulo" incest and "Izu ori" theft of crops or life stock. Other abominable crimes include giving birth to twins "ejima" and "Igbu anu arusi" the killing of screed animals.Such acts require special sacrifice of expiration.

\section{Igbo arts}

According to Cole and Aniakor (1984), Igbo arts are notable for their quantity, quality and diversity. They also stated that creative works in many media were and are still used by various sub-groups of the Igbo - speaking people of Nigeria. 
Plate: $2,3,4$ and 5

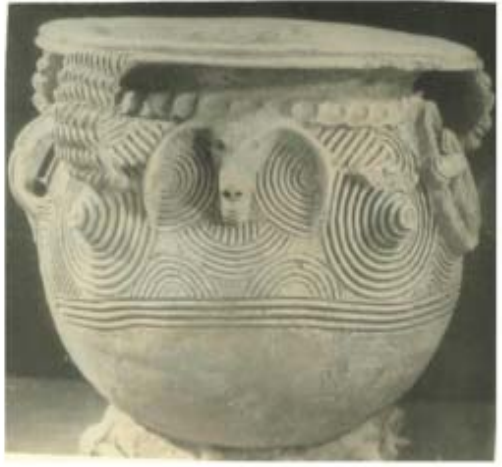

Plate 2 The ritual/ceremonial pot

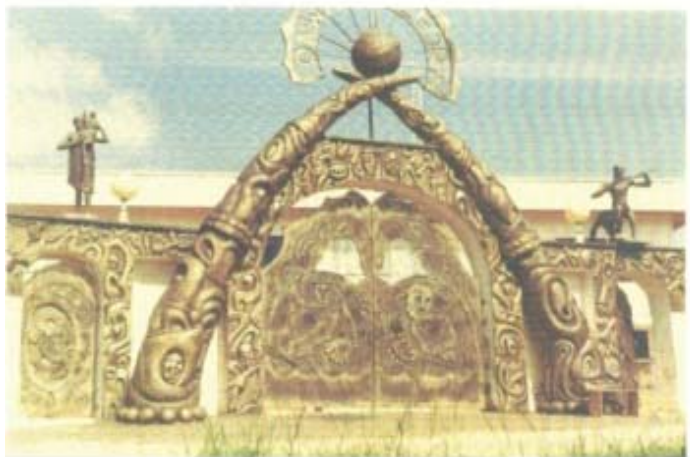

Plate 4 Modern Igbo gate

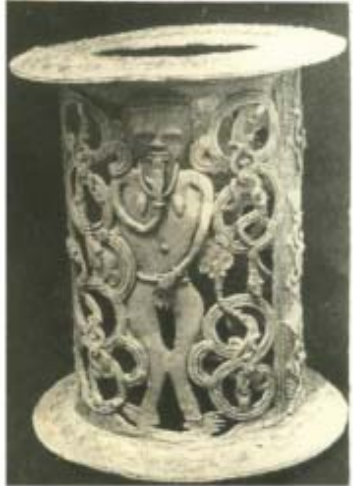

Plate 3 Fronze alter stand. Igbo Ialah. Height $27.4 \mathrm{~cm}$.

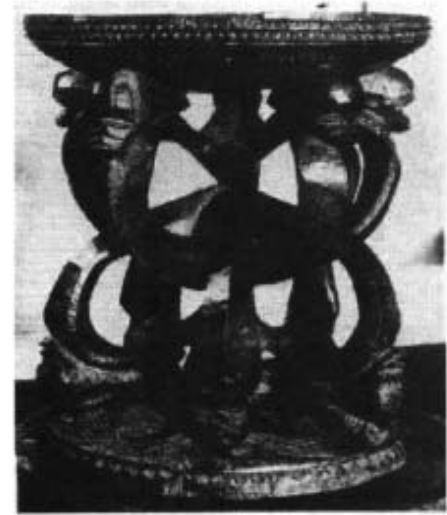

Plate 5 Ceremonial stool for members of Exe Nri society

They also recognized that these arts function simultaneously to improve and reflect the quality of life, to honour gods and to entertain. Furthermore, it was stated that the earliest Igbo art forms were cooper-alloy casting from Igbo-ukwu in the heart of Igbo land. These are also the earliest known fine metal objectsfrom tropical African dating back to the 10th century A.D. Thousands of Igbo art objects were doubtless produced in the intervening centuries (shaw 1970). It also contained that most surviving forms were made in the late $19^{\text {th }}$ and $20^{\text {th }}$ century with wood carving being the dominant medium.

Eyo (1977) mentioned that the main motive for making sculpture in African society until recently, were religions, prestige and festival. He also stated that the display of objects, considered beautiful or expensive has always been main's way of displaying wealth and social status. Again he asserted that as an expression of ostentation and royalty, chiefs and noble men normally commission art works like relief doors which they incorporate in their houses. The beautiful artifacts excavated by Shaw $(1970$ and 1971) attest to the people enormous wealth, high status, social and politicalinfluence and authority. In fact the burial chamber excavated by Shaw from the archeological site of Igbo Richard is a pointer to the artistic and mystical powers given the complex nature of the title regalia of the people. 
Fig. 3

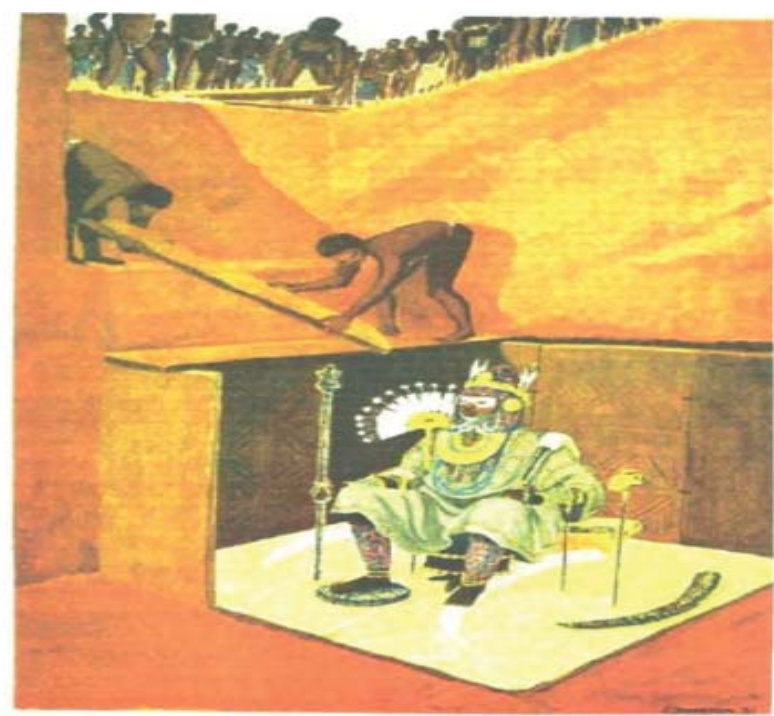

Fig. 3 Igbo-Ukwu. Reconstruction of burial chamber based on excavations and ethnographic data Drawn by Caroline Sassoon.

Furthermore, Fraser injected that the widely held opinion that art is a luxury and serves no vital purpose is a myth as far as Africa is concerned. For apart from having well known social and religious functions, much African arts also play prominent partsin the sphere of political leadership and in governance.

Plate: $6 \& 7$

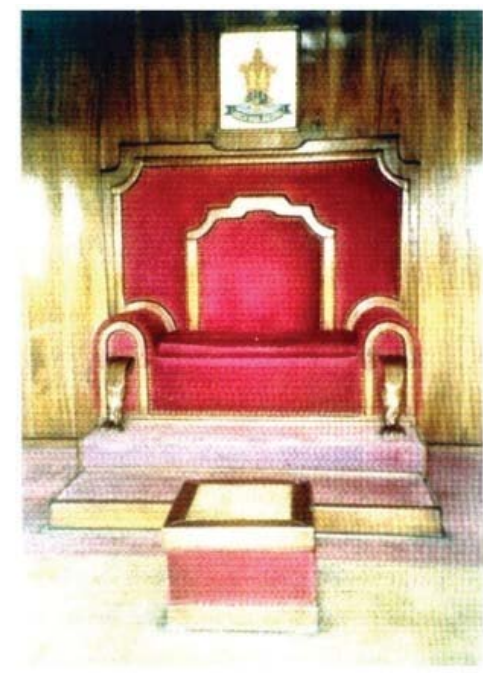

Plate 6 A throne belonging to His Royal Majesty Igwe Alfred Nnaemeka Achebe (Agbogidi), the Obi of Onitsha.

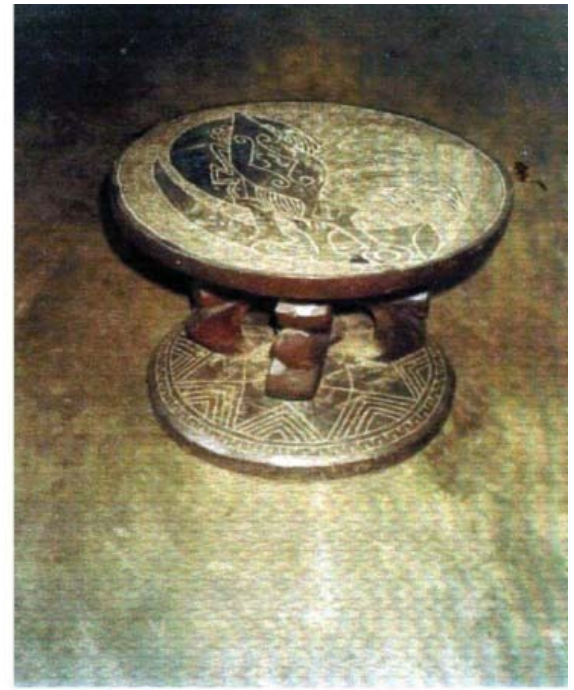

Plate 7 Women's Odu title stool from Achalla in Awka North Local Government Area

These claims, notions and assertions are true in all ramifications and as contained and affirmed in Cole and Aniakor (1984), Onwuegiegwu (1981), Shaw (1970) and(1977), Nzimiro (1972), Jeffreys (1941) and (1977),Henderson \& 
Uumunna (1988), Eyo(1977), Ejizu (1986), Cole (1972) and Boston (1977). These scholarly and quality research writeups all point to the traditional leadership in Igbo Land which is commonly vested in the family level by the family head, the village council among whose member are heads of lineages segments,elders, titled men and others of wealth and positions. These group commission works of art which they use for their personal aggrandizement, political, social, religious fulfillment and supportas well as for the upwards movement of the family and the community. A fact which is embraced upheld and practiced in the entire Igbo world.

Before the advert of the European administrators, lineage segments and individual villages were the largest effective political units found among the Igbo.Although sub-tribal identity was sometimes involved for ritual reasonsor in the time of wars. This political and social fragmentations, reinforced by numerous dialectical different in Igbo language is parallel by the diversity of leadership and land tenure system,religious beliefs and art styles found in Igbo area. Yet, there are also very strong common bounds in the relationship of leadership governance and art for all Igbo people.

Again, there are also varieties of art forms that have served to reflect, uphold and materialize social, political and religious authority in comparable ways among Igbo group. The role of art in one typical Igbo institution among many; the Ozo title institution serves to show how art, leadership and governance reinforce one another in the entire Igbo culture.

Plate: 8
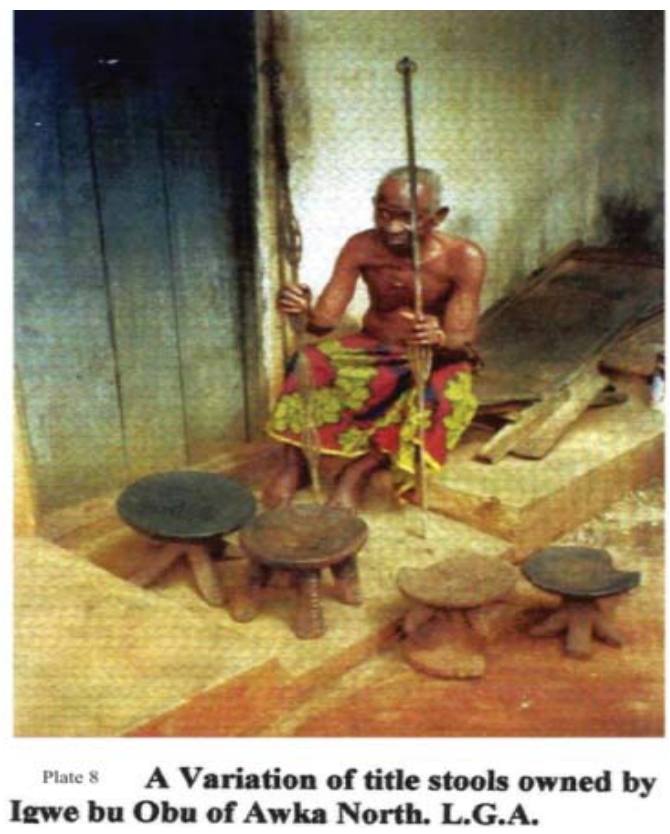

\section{Conclusion}

The study background shows the historical sequences of the development of the Igbo nation; their territory, space and area coverage, occupational distribution as well as their occupational/cultural area. Other areas touched in this study include the people's myth of creation and migration patterns. It was also discovered that their dispersal pattern of settlement was not a bridge to their homogenous nature. This is because of their indispensable worldview with strong hold in overwhelming and wholesome acceptance of their tradition which is embedded in the cutting/presentation of kola nut, thepouring of libation, the uncompromising use of "Ofo" as the symbol of truth and justice as well as the distinctive features of their tile taking,.

Furthermore, the peoples general and uniform acceptance of chukwu okike and other smaller gods and their ideology of abomination which cut across the entire lgbo land and culminated in their artistic, social, religious as well as political institution and pattern of leadership system are strong points to their homogeneity.

Interestingly, the moral codes of this dynamic people which is rooted in their religion and summed up in their "Omenani" that which happen in the land is another binding force among the Igbo's. 
Although, there are few political and social fragmentation and dialecticaldifferences, traces of cultural patterns extended throughout the area of Igbo society. Yet, there are very strong and common bounds in the relationship of leadership, social, economic, religious as well as arts for all the Igbo people which serve to show, reflect, uphold and materialize in comparable ways among the Igbo people, a fact which integrated the people. Hence, onecannot but pronounce in strong terms that this genus and unique culture is homogenous.

This study we believe may steer a research into other aspect of the Igbo characteristic by trying to find out that which may piece their frontier become according to an Igbo adage "ihe di abua abua" meaning that things are in twos; hence "ihe kwaru ihe akwadabeya" meaning that when something stands; something else stands by it.

\section{Reference}

Afigbo, A.E (1981) Ropes of Sand: Studies in Igbo History and culture. Nsukka; University of Nigeria press.

Aniakor, C.C (1973) Structuralim in Ikenga: An ethnoaesthetic approach. Journal of Africa Studies University of Nigeria caxton press. West Africa Limited 8:9-1)

Aniakor, C.C (1978) Igbo Architecture: A study of forms functions ad typology (1)

Aniakor, C.C (2002). "Art in the culture of Igbo land" In G.E.K Ofomata (ed). A survey of Igbo nation. (pp. 300 - 349). Onitsha: African first publishers limited.

Basden, G.T. (1938) Niger Ibos. London: frank Cass and company Limited.

Boston, J.B (1977), Ikenga Figures among the north - west Igbo and Igala; Lagos: federal Department of Antiquities.

Chikwendu, V.E and Umeji A, (1983) LOcal Sources of Raw materials for Nigerian bronze industry. West African journal of Archaeology (9) $151-165$

Cole, H.M (1972) "Igbo Art and Authority" In D Fraser and H.M Cole (eds), African arts and leadership (pp 79-97) Madison: University of Wisconsin Press.

Cole H.M and Aniakor, C.C (1984). Igbo Arts: community and cosmos: University of California: Museum of Cultural History

Dike K.O (1956) Trade and politics in the Niger delta, 1930 - 1985; an introduction to the economic and political history of Nigeria. Oxford clarendon press.

Ejizu C.I (1986) Ofo: Igbo ritual symbol. Enugu: Fourth Dimension Publishing Company Limited.

Eliade, M (1987) in the Encyclopedia of religion (Vol. 6. Pp1) New York: Macmillan Publishing Company.

Eyo, E (1977) two thousand years Nigerian Art. Lagos Nigeria. Federal Department of Antiquities.

Hartle, D (1956) "Archaeology in Eastern Nigeria" Nigeria Magazine (93) 134 - 143

Henderson, R and Umuma, I (1988) "Leadership Symbolism in Onitsha Igbo Crown and ljele" Africa Arts xxi (2), 28 - 37

Jeffreys, M.D.W (1941) "letter on awka Bronzes" in Nigerian Field: 140 - 142

Jeffrets M.D (1977), "Extract" in T. Shaw (ed) unearthing Igbo Ukwu: Archaeological discoveries in eastern Nigeria: London: Oxford University Press

Jones G.J (1970) Training state of the oil rivers. London: Oxford university press

Karmon, Y (1966). A geography of settlement in Eastern Nigeria. Jerusalem: Magnes Press. Hebrew University.

Morgan; R.S Worldridge, S.W (1959). An outline of geomorphology. The physical basis of geography. England: Longmans

Nwala, U. T. (1985), Igbo Philosophy. Lagos: Lantern Books

Nzimiro I, (1972). Studies in Igbo political systems, chieftaincy and politics in four Niger States: London: Frank Cass and company Limited

Obayemi; A (1980) "states and people of the Niger-Benue confluence area". In Ikimi (ed) Groundwork of Nigerian History (pp144-164). London: Longman

Ogbalu F. C (N.D). Igbo Institutions and customs. Onitsha University press

Ogbukagu I. (1997). Traditional Igbo beliefs and practices: A study of culture and people of Adazi- Nnuku. Owerri: Novelty Industrial Enterprise Limited.

Onwuejeogwu, A.M (1981) an Igbo civilization: Nri Kingdom and hegemony

Shaw T. (1970) Igbo - Ukwu: an account of archaeological discovenient in Eastern Nigeria: London: Faber and Limited.

Shaw T. (1977) Unearthing Igbo-Ukwu: Archeology discoveries in eastern Nigeria. London. Oxford University press.

Uchendu; V.C. (1965). The Igbo of Southeast Nigeria. London Rinehart and Winston incorporated. 